\title{
Synthesis of umbelliferone derivatives in Escherichia coli and their biological activities
}

Luan Luong Chu', Ramesh Prasad Pandey ${ }^{1,2}$, Haet Nim Lim', Hye Jin Jung ${ }^{1,2}$, Nguyen Huy Thuan ${ }^{3}$, Tae-Su Kim$^{1}$ and Jae Kyung Sohng ${ }^{1,2^{*}}$

\begin{abstract}
Background: Umbelliferone, also known as 7-hydroxycoumarin, is a phenolic metabolite found in many familiar plants. Its derivatives have been shown to have various pharmacological and chemo-preventive effects on human health. A uridine diphosphate glycosyltransferase YjiC from Bacillus licheniformis DSM 13, a cytochrome P450BM3 (CYP450 BM3) variant namely mutant 13 (M13) from Bacillus megaterium, and an O-methyltransferase from Streptomyces avermitilis (SaOMT2) were used for modifications of umbelliferone.
\end{abstract}

Results: Three umbelliferone derivatives (esculetin, skimmin, and herniarin) were generated through enzymatic and whole cell catalysis. To improve the efficiencies of biotransformation, different media, incubation time and concentration of substrate were optimized and the production was scaled up using a 3-L fermentor. The maximum yields of esculetin, skimmin, and herniarin were $337.10 \mu \mathrm{M}(67.62 \%), 995.43 \mu \mathrm{M}(99.54 \%)$, and $37.13 \mu \mathrm{M}(37.13 \%)$, respectively. The water solubility of esculetin and skimmin were 1.28-folds and 3.98-folds as high as umbelliferone, respectively, whereas herniarin was 1.89-folds less soluble than umbelliferone. Moreover, the antibacterial and anticancer activities of herniarin showed higher than umbelliferone, esculetin and skimmin.

Conclusions: This study proves that both native and engineered enzymes could be employed for the production of precious compounds via whole cell biocatalysis. We successfully produced three molecules herniarin, esculetin and skimmin in practical amounts and their antibacterial and anticancer properties were accessed. One of the newly synthesized molecules the present research suggests that the combinatorial biosynthesis of different biosynthetic enzymes could rapidly promote to a novel secondary metabolite.

Keywords: Glycosylation, Hydroxylation, Methylation, Umbelliferone

\section{Background}

Umbelliferone and its derivatives are compounds derived from coumarin (Fig. 1) with pharmacological and chemopreventive benefits for human health. Umbelliferone is known to have antinociceptive and anti-inflammatory activities in animal models [1]. Moreover, esculetin exhibits various biological activities including antioxidant

\footnotetext{
* Correspondence: sohng@sunmoon.ac.kr

'Department of Life Science and Biochemical Engineering, Sun Moon University, 70 Sunmoon-ro 221, Tangjeong-myeon, Asan-si, Chungnam 31460, Republic of Korea

2Department of BT-Convergent Pharmaceutical Engineering, Sun Moon University, 70 Sunmoon-ro 221, Tangjeong-myeon, Asan-si, Chungnam 31460, Republic of Korea

Full list of author information is available at the end of the article
}

[2], anti-tumor, anti-metastatic [3], anti-proliferative, proapoptotic [4], and neuroprotective activities [5]. Umbelliferone glycosides have been found to possess neuroprotective effects against serum deprivation-induced PC12 cell damage [6] with antidiabetic, antihyperlipidemic, and antioxidative activities [7]. Furthermore, 7-methoxycoumarin showed antifugal and antibacterial activities [8]. Likewise, other umbelliferone derivatives such as scopoletin, scoparone, fraxetin, esculin, and daphnetin have been reported to have antioxidant and intestinal anti-inflammatory activities [9].

Coumarins are phenolic metabolites commonly distributed in many plant species [10]. The ortho-hydroxylation of cinnamate is a pivotal step in the biosynthesis of 


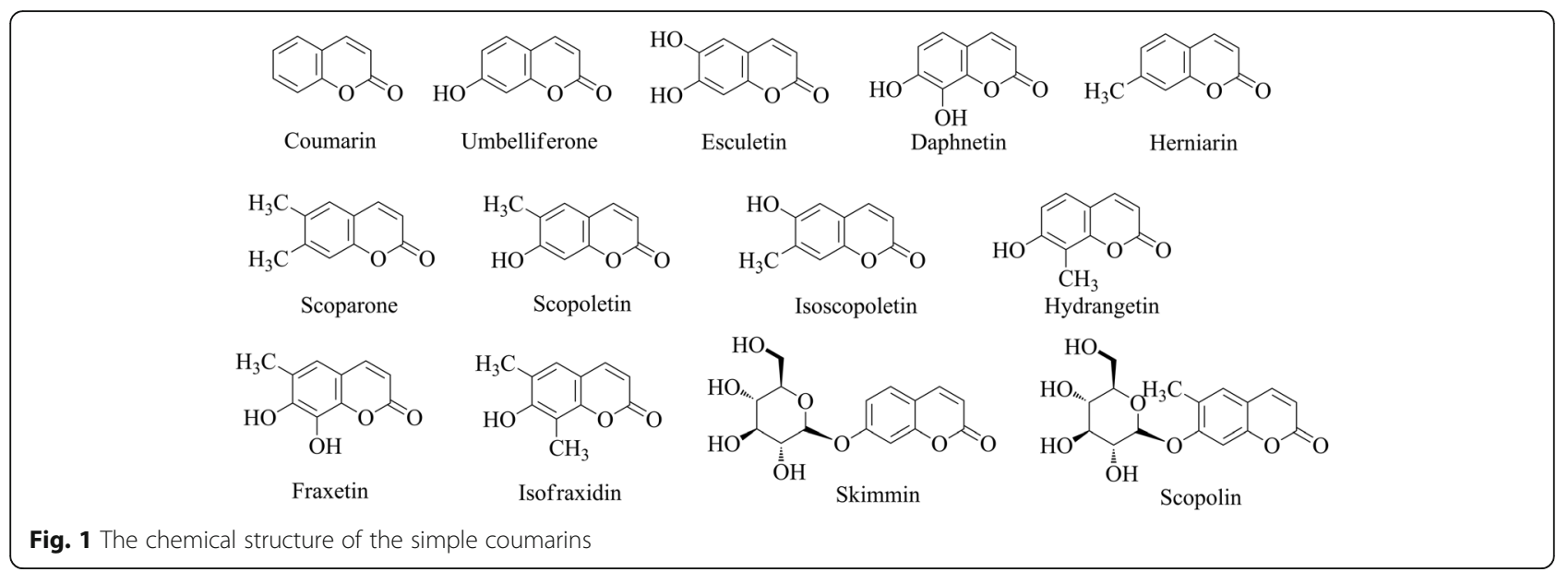

coumarin in plants. The core structure, $2 H$-1-benzopyran2 -one, of umbelliferone and its derivatives are formed via ortho-hydroxylation of cinnamates which undergo trans/ cis isomerization of the side-chain followed by lactonization [11]. Although these compounds exhibit multibeneficial pharmacological properties, isolation and purification of umbelliferone and its derivatives from plants are problematic due to low concentration and seasonal and regional dependency [12]. On the other hand, chemical synthesis requires the usage of hazardous agents, long synthetic steps, and extreme reaction conditions $[13,14]$.

Recently, an alternative approach has emerged as a promising method to synthesize small molecules by engineering microbes. Simple coumarins have been obtained from engineered Escherichia coli (E. coli) by combinational expression of artificial pathway enzymes with diverse genetic source including phenylalanine ammonia lyase (PAL) or tyrosine ammonia lyase (TAL), 4-cinnamic acid:coenzyme A ligase (4CL), coumarin synthase $\left(\mathrm{C} 2^{\prime} \mathrm{H}\right.$, coumaroyl-CoA 2'-hydroxylase; or F6' $\mathrm{H}$, feruloyl-CoA 6' hydroxylase) [15-17]. For example, umbelliferone and scopoletin have been synthesized by using TAL, HpaBC (4hydroxyphenylacetate 3-hydroxylase), and CCoAOMT (caffeoyl-CoA $O$-methyltransferase) in conjunction with $4 \mathrm{CL}$ and $\mathrm{F}^{\prime} \mathrm{H}$ from $p$-coumaric acid and ferulic acid, respectively [16]. Moreover, tyrosine can be converted to esculetin by employing TAL, C3H (coumarate 3-hydroxylase from E.coli) or Sam5 (a monooxygenase from Saccharothrix espanaensis), 4CL, and $\mathrm{F}^{\prime} \mathrm{H}[17,18]$. These researches demonstrated that hydroxyl cinnamic acid or glucose was the strating material for biosynthesis of simple coumarins. However, low catalytic activity, low final yield, and limited products are the most frequently encountered problems when applying a combinatorial expression approach.

In this study, biocatalyst system was carried out to modify umbelliferone by using glycosyltransferase, cytochrome P450, and O-methyltransferase. Three derivatives of umbelliferone, namely esculetin, skimmin, and herniarin, were successfully synthesized and their antibacterial and anticancer activities were evaluated.

\section{Results}

Protein expression and purification

Recombinant proteins CYP450 BM3 (119 kDa), M13 (119 kDa), YjiC (45 kDa), and SaOMT2 (37.5 kDa) were overexpressed in E. coli BL21 (DE3) (Additional file 1: Figure S1). The content acquired from the soluble fractions of proteins CYP450 BM3 and M13 were 477.253 and $1932.069 \mathrm{nM} / \mathrm{L}$, respectively. The concentrations of crude proteins of CYP450 BM3, M13, YjiC, and SaOMT2 were determined to be approximately 147.54, 122.93, 344.28, and $76.99 \mu \mathrm{g} / \mathrm{mL}$, respectively, based on the Bradford method.

\section{Enzymatic reaction}

The four enzymes was performed enzymatic reaction using umbelliferone as standard substrate. The results were analyzed by high performance liquid chromatographyphotodiode array (HPLC-PDA) and high-resolution quadruple time-of-flight electrospray ionization-mass spectrometry (HR-QTOF ESI/MS). The retention time $\left(t_{\mathrm{R}}\right)$ of umbelliferone standard was observed at $13.749 \mathrm{~min}$ with UV absorbance at $330 \mathrm{~nm}$ (Fig. 2a(i)). The found mass of umbelliferone was $\sim 163.0394[\mathrm{M}+\mathrm{H}]^{+} \mathrm{m} / z^{+}$equivalent to molecular formula $\mathrm{C}_{9} \mathrm{H}_{7} \mathrm{O}_{3}$, for which the calculated mass was 163.0395 (Additional file 1: Figure S2A). HPLCPDA chromatogram revealed the appearance of a new peak (P1) in the hydroxylation reaction of both CYP450 BM3 and M13. A new peak $t_{\mathrm{R}}$ at $12.730 \mathrm{~min}$ (Fig. 2a(ii;iii)) and $\lambda_{\max }$ at $325 \mathrm{~nm}$ might be hydroxylated umbelliferone. P1 was further analyzed by HR-QTOF ESI/MS. The mass spectrum displayed a peak with found mass of $\sim 179.0390[\mathrm{M}+\mathrm{H}]^{+} \mathrm{m} / \mathrm{z}^{+}$, resembling the mass of mono-hydroxylated derivative of umbelliferone with a molecular formula $\mathrm{C}_{9} \mathrm{H}_{7} \mathrm{O}_{4}$, for which the calculated 

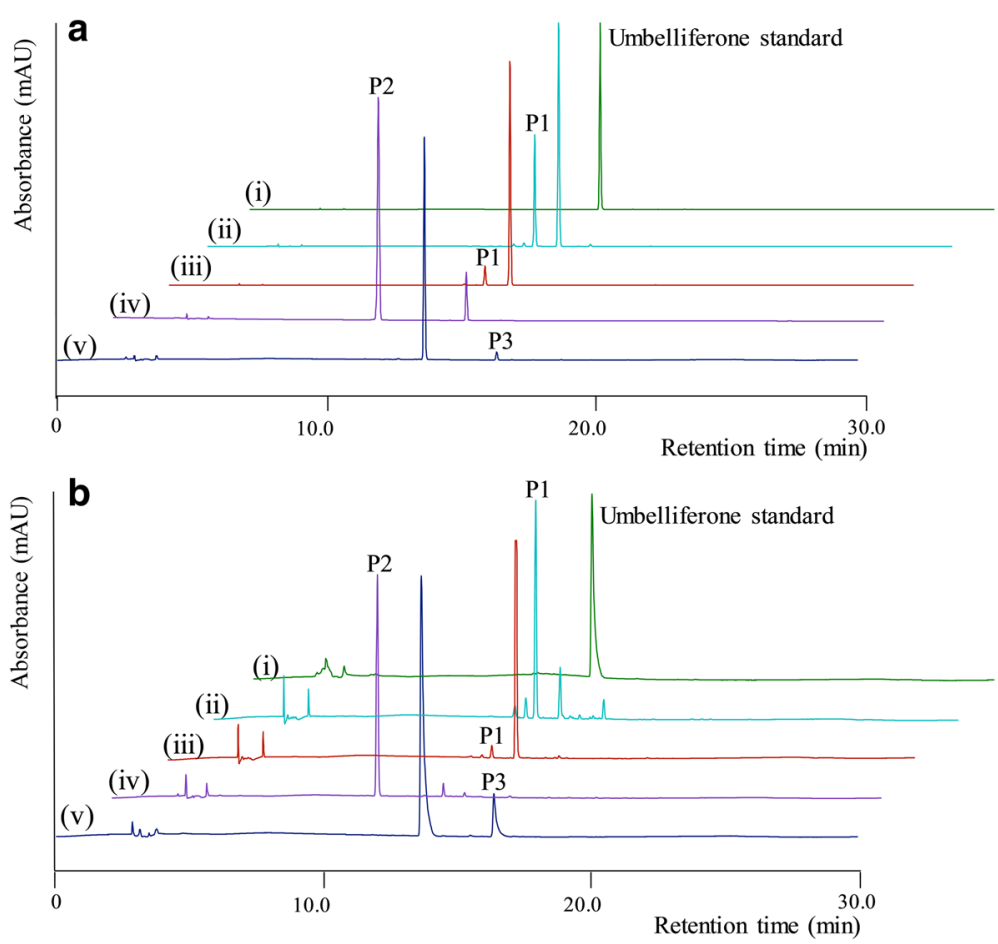

Fig. 2 a In vitro reaction mixture and $\mathbf{b}$ whole cells bioconversion of umbelliferone on the HPLC-PDA analysis. (i) control reaction of umbelliferone using E. coli BL21 (DE3); (ii) hydroxylation with M13 and (iii) CYP450 BM3 at 48 h; (iv) glycosylation with YjiC at 12 h; and (v) methylation with SaOMT2 at $48 \mathrm{~h}$, respectively

mass was 179.0344 (Additional file 1: Figure S2B). HPLC-PDA analysis showed that M13 had higher catalytic activity $(35.48 \%)$ as a monooxygenase than CYP450 BM3 in which the conversion was limited to 8.29\% (Table 1, Fig. 2a(iii)). Moreover, the HPLC-PDA analysis of glycosylation reaction mixture showed a new peak at $t_{\mathrm{R}}$ of $10.323 \mathrm{~min}$ (P2) (Fig. 2a(iv)). P2 exhibited the found mass $[\mathrm{M}+\mathrm{H}]^{+} \mathrm{m} / \mathrm{z}^{+}$at $\sim 325.0912$ with $\lambda_{\text {max }}: 317 \mathrm{~nm}$, corresponding to the calculated mass of the mono-glucoside derivative of umbelliferone with molecular formula $\mathrm{C}_{15} \mathrm{H}_{17} \mathrm{O}_{8}$ for $[\mathrm{M}+\mathrm{H}]^{+} \mathrm{m} / \mathrm{z}^{+} \sim$ 325.0923 (Additional file 1: Figure S2C). Furthermore, the HPLC-PDA analysis of methylation reaction mixture exhibited an additional peak at at $t_{\mathrm{R}}$ of $16.381 \mathrm{~min}$
(P3) (Fig. 2a(v)). P3 showed the exact mass $[\mathrm{M}+\mathrm{H}]^{+}$ $\mathrm{m} / \mathrm{z}^{+}$at $\sim 177.0553$ with $\lambda_{\text {max }}: 321 \mathrm{~nm}$, corresponding to the calculated mass of methylated umbelliferone with molecular formula $\mathrm{C}_{10} \mathrm{H}_{9} \mathrm{O}_{3}$ for $[\mathrm{M}+\mathrm{H}]^{+} \mathrm{m} / z^{+} \sim$ 177.0552 (Additional file 1: Figure S2D). The result displayed the conversion of umbelliferone to its derivatives were $86.45 \%$ and $2.08 \%$ in the glycosylation and methylation reactions, respectively (Table 1 ). These in vitro results indicated that umbelliferone might be a substrate of various transferase enzymes. It was converted more efficiently to glycosylated form than other derivatives. Therefore, umbelliferone was used for the production of its derivatives by using M13, YjiC, and SaOMT2 in whole cells.

Table 1 The HPLC-PDA, chemical formula, HR-QTOF ESI/MS, UV maxima and conversion product analyses of umbelliferone in in vitro reaction using CYP450 BM3 and its variant proteins M13, YjiC and SaOMT2

\begin{tabular}{|c|c|c|c|c|c|c|c|}
\hline Name & & $\operatorname{HPLC}\left(t_{R}\right) \min$ & Chemical formula & $\begin{array}{l}\text { Calculated mass } \\
{[\mathrm{M}+\mathrm{H}]^{+} \mathrm{m} / \mathrm{z}^{+} \sim}\end{array}$ & $\begin{array}{l}\text { Exact mass } \\
{[\mathrm{M}+\mathrm{H}]^{+} \mathrm{m} / \mathrm{z}^{+} \sim}\end{array}$ & UV maxima (nm) & $\%$ Conversion \\
\hline Substrate & Umbelliferone & 13.749 & $\mathrm{C}_{9} \mathrm{H}_{6} \mathrm{O}_{3}$ & 163.0395 & 163.0394 & 327 & \\
\hline \multirow[t]{4}{*}{ Products } & $\begin{array}{l}\text { Hydroxylated (P1) } \\
\text { by P450 BM3 }\end{array}$ & 12.730 & $\mathrm{C}_{9} \mathrm{H}_{6} \mathrm{O}_{4}$ & 179.0344 & 179.0390 & 325 & 8.09 \\
\hline & $\begin{array}{l}\text { Hydroxylated (P1) } \\
\text { by M13 }\end{array}$ & & $\mathrm{C}_{9} \mathrm{H}_{6} \mathrm{O}_{4}$ & & & & 35.48 \\
\hline & Glycosylated (P2) & 10.323 & $\mathrm{C}_{15} \mathrm{H}_{16} \mathrm{O}_{8}$ & 325.0923 & 325.0912 & 317 & 86.45 \\
\hline & Methylated (P3) & 16.381 & $\mathrm{C}_{10} \mathrm{H}_{8} \mathrm{O}_{3}$ & 177.0344 & 177.0547 & 321 & 2.08 \\
\hline
\end{tabular}




\section{Bioconversion of umbelliferone using CYP450 BM3 and its variant}

The hydroxylated derivative was produced from umbelliferone by using $E$. coli harboring $\mathrm{pCW}\left(\mathrm{Ori}^{+}\right)$-CYP450 BM3 wild type and $E$. coli harboring $\mathrm{pCW}\left(\mathrm{Ori}^{+}\right)$-mutant 13 (M13). The cells were induced with IPTG and were incubated at $28{ }^{\circ} \mathrm{C}$ with $100 \mu \mathrm{M}$ umbelliferone for $12 \mathrm{~h}$ in various media as described in materials and methods. Culture media and cell pellets were extracted with ethyl acetate (EtOAc) and the products were analyzed by HPLC-PDA. HPLC-PDA chromatograms of both strains showed a new peak at $t_{R} \sim 12.730 \mathrm{~min}$ (P1) in comparison with umbelliferone standard at $t_{R} \sim 13.749$ min under UV absorbance of $330 \mathrm{~nm}$ (Fig. 2b(i; ii)). All detected peaks were further analyzed by HR-QTOF ESI/MS. The found mass of umbelliferone standard was observed at 163.0394 $[\mathrm{M}+\mathrm{H}]^{+} \mathrm{m} / z^{+}$corresponding to molecular formula $\mathrm{C}_{9} \mathrm{H}_{7} \mathrm{O}_{3}$ with $\lambda_{\max } \sim 327 \mathrm{~nm}$, for which the calculated mass was 163.0395 (Additional file 1: Figure S2A). The found mass of hydroxylated product P1 at $\sim 179.0390$ $[\mathrm{M}+\mathrm{H}]^{+} \mathrm{m} / z^{+}$corresponding to molecular formula $\mathrm{C}_{9} \mathrm{H}_{7} \mathrm{O}_{4}$ with $\lambda_{\max } \sim 325 \mathrm{~nm}$, for which the calculated mass was $~ 179.0344$ (Additional file 1: Figure S2B).

The bioconversion rate of umbelliferone to hydroxylated products was very low with the wild type strain using all three different media. However, the conversion was relatively higher with E. coli BL21(DE3) harboring pCW $\left(\mathrm{Ori}^{+}\right)$-mutant 13 (M13). The highest hydroxylated product was recorded to be $84.70 \mu \mathrm{M}$ (84.7\% conversion) in M9 medium, which was 1.85 -fold higher than that in Luria-Bertani (LB) medium (45.72 $\mu \mathrm{M})$ and 2.07-fold higher than that in Terrific Broth (TB) medium $(40.84 \mu \mathrm{M})$ (Additional file 1: Figure S3A). These results further mean that M9 medium was a suitable medium for the production of hydroxylated product from umbelliferone. Similar trend has been observed with other flavonoid molecules [19]. However, the exact reason behind this is unclear. After that, E. coli BL21(DE3) harboring $\mathrm{pCW}\left(\mathrm{Ori}^{+}\right)$-mutant 13 was chosen to optimize the substrate conversion with separately supplied 100, 250, 500, 750, and $1000 \mu \mathrm{M}$ of umbelliferone. Substrate utilization and cell growth were measured at $12 \mathrm{~h}$ intervals. The maximum concentration of hydroxylated product was $329.29 \mu \mathrm{M}(65.86 \%)$ at $48 \mathrm{~h}$ with $\mathrm{OD}_{600} \sim 3.949$ when $500 \mu \mathrm{M}$ of umbelliferone was added into the biotransformation reaction. Even though umbelliferone was non-toxic to cells (Additional file 1: Figure S3B), bioconversion was inhibited when a higher amount of substrate was supplied (Additional file 1: Figure S3C). Recombinant strain E. coli BL21(DE3) harboring $\mathrm{pCW}\left(\mathrm{Ori}^{+}\right)$-mutant 13 were cultured in a 3 - $\mathrm{L}$ fermentor with $1 \times \mathrm{M} 9 \mathrm{~min}$ imal medium supplemented with $500 \mu \mathrm{M}$ umbelliferone ( 243.2 $\mathrm{mg}$ in 3-L) and supplied $2 \%$ glucose. The temperature and $\mathrm{pH}$ of the fermentor were kept constant at $28{ }^{\circ} \mathrm{C}$ and 7.6 , respectively. The samples were taken at $12 \mathrm{~h}$ interval and measured by HPLCPDA. Only $377.0959 \mu \mathrm{M}(\sim 180.2 \mathrm{mg} ; 60.1 \mathrm{mg} / \mathrm{L})$ of hydroxylated umbelliferone was produced until $48 \mathrm{~h}$ as the maximal yield with bioconversion rate of the substrate at $\mathrm{OD}_{600} \mathrm{~nm} \sim 43.37$ of approximately $67.62 \%$ (Fig. 3a).

\section{Production of glucosylated umbelliferone}

The glucosylated derivative was synthesized from umbelliferone by using E.coli harboring pET28a-YjiC. This E. coli strain was fed with $100 \mu \mathrm{M}$ substrate at $20{ }^{\circ} \mathrm{C}$ for $12 \mathrm{~h}$ in various media. The product was extracted with twice volume of EtOAc. HPLC-PDA analysis showed a new peak (P2) with $t_{\mathrm{R}} \sim 10.323 \mathrm{~min}$ compared to $t_{\mathrm{R}} \sim$

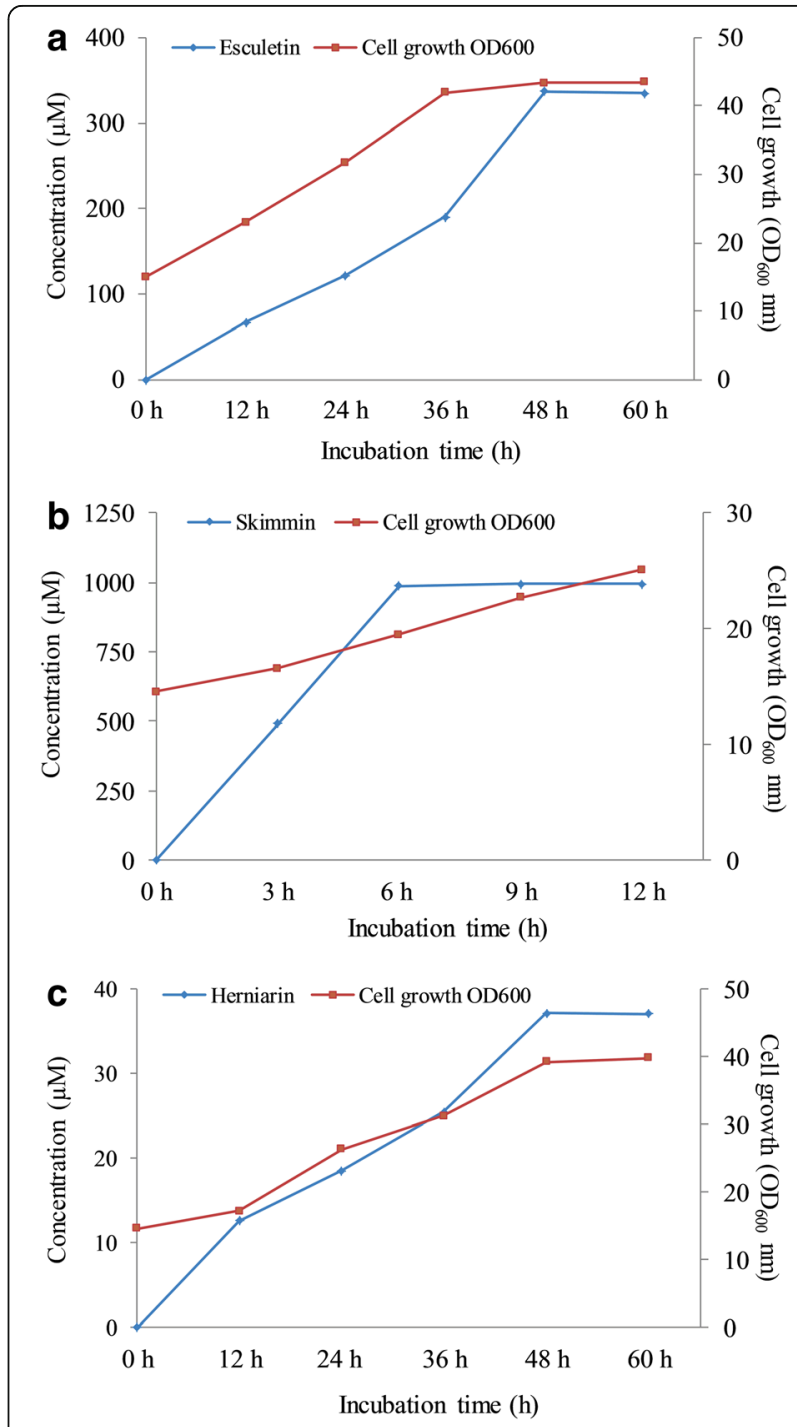

Fig. 3 The scale-up of $\mathbf{a}$ hydroxylated $\mathbf{b}$ glucosylated $\mathbf{c}$ methylated umbelliferone and cell growth at $\mathrm{OD}_{600} \mathrm{~nm}$ in 3-L fermentation at different time intervals 
$13.749 \mathrm{~min}$ of a substrate under UV absorbance of $330 \mathrm{~nm}$ (Fig. 2b(i; iii)). The found mass of glycosylated product $\mathrm{P} 2[\mathrm{M}+\mathrm{H}]^{+} m / z^{+}$was $\sim 325.0912$, resembling molecular formula $\mathrm{C}_{15} \mathrm{H}_{7} \mathrm{O}_{8}$ with $\lambda_{\max } \sim 317 \mathrm{~nm}$. The calculated mass was $\sim 325.0923$ (Additional file 1: Figure S2C). While the highest bioconversion of umbelliferone to glucosylated derivative was observed in M9 medium (99.65 $\mu \mathrm{M}, 99.65 \%)$, which was lower in both LB $(58.70 \mu \mathrm{M}, 58.70 \%)$ and $\mathrm{TB}(46.91 \mu \mathrm{M}, 46.91 \%)$ media under identical reaction conditions. (Additional file 1: Figure S4A). The different concentration of umbelliferone $(100,500,1000,1500$ and $2000 \mu \mathrm{M})$ was fed into the culture of E.coli harboring pET28a-YjiC in the M9 $1 \mathrm{x}$ medium. An equal volume of sample was taken and analyzed at $3 \mathrm{~h}$ intervals. Time and concentration dependent study showed that the highest concentration of umbelliferone glucoside was $996.72 \mu \mathrm{M}$ (99.67\%) with $\mathrm{OD}_{600} \sim 3.06$ at $12 \mathrm{~h}$ when $1000 \mu \mathrm{M}$ of substrate was supplemented in the culture. Umbelliferone failed to affect the growth rate of cells (Additional file 1: Figure S4B). However, the amount of glycosylated product was not significantly increased when a higher amount of substrate was supplied (Additional file 1: Figure S4C). Therefore, $1000 \mu \mathrm{M}$ umbelliferone and 1x M9 minimal medium with $2 \%$ glucose were selected for the scale up of bioconversion reaction in 3-L fermentor. Nearly all umbelliferone was transformed into glycosylated product at $6 \mathrm{~h}$, yielding approximately $995.43 \mu \mathrm{M}(\sim 967.6 \mathrm{mg}$; $322.8 \mathrm{mg} / \mathrm{L}$ ) of product with $\mathrm{OD}_{600} \mathrm{~nm} \sim 22.7$ (Fig. 3b).

\section{Whole cell methylation of umbelliferone}

E. coli harboring pRSF-Duet-SaOMT2 was subjected to methylation process of umbelliferone. The biotransformation system was supplied with $100 \mu \mathrm{M}$ and incubated at $20{ }^{\circ} \mathrm{C}$ for $48 \mathrm{~h}$ in various media. The product was extracted with EtOAc and analyzed by HPLC-PDA. The result showed methylation product of substrate with a peak at $t_{\mathrm{R}} \sim 16.381 \mathrm{~min}$ whereas the aglycone moiety of umbelliferone appeared at $t_{\mathrm{R}} \sim 13.749 \mathrm{~min}$ (Fig. $2 \mathrm{~b}$ (iv)). Subsequently, the peak at $t_{\mathrm{R}} \sim 16.381 \mathrm{~min}$ was further analyzed by HR-QTOF ESI/MS. The observed mass $[\mathrm{M}+\mathrm{H}]^{+} \mathrm{m} / \mathrm{z}^{+}$was $\sim 177.0553$, resembling molecular formula $\mathrm{C}_{10} \mathrm{H}_{1}{ }_{9} \mathrm{O}_{3}$ with $\lambda_{\max } \sim 321 \mathrm{~nm}$. The calculated mass of methylated umbelliferone was $\sim 177.0552$ (Additional file 1: Figure S2D).

Unlike hydroxylation and glycosylation reactions in whole cell biotransformation, methylated product was produced at maximum concentration $(17.61 \mu \mathrm{M}, 17.61 \%$ conversion) after $48 \mathrm{~h}$ incubation in LB media, followed by that in M9 $(2.60 \mu \mathrm{M}, 2.6 \%)$ and TB media $(1.15 \mu \mathrm{M}$, $1.15 \%$ ) (Additional file 1: Figure S5A). The results of optimized conversion showed that the maximum concentration of methylated product was $17.61 \mu \mathrm{M}(17.61 \%)$ at $48 \mathrm{~h}$ with $\mathrm{OD}_{600} \sim 3.45$ when $100 \mu \mathrm{M}$ of umbelliferone was added into the biotransformation reaction (Additional file 1: Figure S5B). Umbelliferone did not affect the growth rate of cells. However, the bioconversion from a substrate to the methylated product was not meaningfully increased when a higher amount of substrate was supplied (Additional file 1: Figure S5C). To test the reproducibility of the bioconversion process into the large-scale fermentor, batch fermentation of this strain was carried out in a 3-L fermentor with LB medium supplied with umbelliferone at $100 \mu \mathrm{M}(\sim 48.64 \mathrm{mg}$ in $3-\mathrm{L})$. The temperature and $\mathrm{pH}$ of the fermentor were maintained at $25{ }^{\circ} \mathrm{C}$ and 7.6 , respectively. The samples were detached at $12 \mathrm{~h}$ interval and measured by HPLC-PDA. HPLC-PDA analysis revealed that methylated product bioconversion was increased to $37.13 \mu \mathrm{M}(\sim 19.6 \mathrm{mg}$; $6.5 \mathrm{mg} / \mathrm{L}$ ) at $48 \mathrm{~h}$ with $\mathrm{OD}_{600} \mathrm{~nm} \sim 39.21$ (Fig. 3c).

\section{Structural elucidation of umbelliferone and its derivatives} The structures of umbelliferone standard and purified modified products were analyzed by proton nuclear magnetic resonance $\left({ }^{1} \mathrm{H}-\mathrm{NMR}\right)$ and carbon-13 nuclear magnetic resonance $\left({ }^{13} \mathrm{C}-\mathrm{NMR}\right)$ at $700 \mathrm{MHz}$ in dimethyl sulfoxide- $\mathrm{d}_{6}\left(\mathrm{DMSO}-d_{6}\right)$. We re-confirmed umbelliferone based on the previous report (Additional file 1: Figure S6) [20]. The ${ }^{1} \mathrm{H}$-NMR spectrum of hydroxylated umbelliferone showed the absence of proton signal at $\delta=6.79 \mathrm{ppm}$ $(J=8.4,2.3 \mathrm{~Hz})$ for $\mathrm{C}-6$. It showed the presence of a new signal at $\delta=10.09 \mathrm{ppm}$ (s) for a hydroxyl group. An upfield shift at $\delta=139.02 \mathrm{ppm}$ of the C- 6 of hydroxylated product was also observed in comparison with the same carbon of umbelliferone at $\delta=113.59 \mathrm{ppm}$ accompanied with a downfield shift of the resonances of adjacent carbons C-7 at $\delta=158.21 \mathrm{ppm}$ and $\delta=160.92 \mathrm{ppm}$, respectively (Table 2; Additional file 1: Figure S7). Furthermore, the compound was identical to an authentic sample of esculetin, a hydroxylated derivative of umbelliferone [21].

In addition, ${ }^{1} \mathrm{H}$-NMR study of the purified glycosylated product displayed the presence of an anomeric proton at $\delta=5.03 \mathrm{ppm}\left(\mathrm{d}, J=7.5 \mathrm{~Hz}, \mathrm{H}-1^{\prime}\right)$ with a beta $(\beta)$ configuration of the sugar moiety, whereas the sugar region observed between $\delta$ of 3.13 and $4.28 \mathrm{ppm}$. In ${ }^{13} \mathrm{C}$-NMR, 6 carbon signals of the $O$-glucoside moiety were found at $\delta=100.43\left(\mathrm{C}-1^{\prime}\right), \delta=73.52\left(\mathrm{C}-2^{\prime}\right), \delta=77.57\left(\mathrm{C}-3^{\prime}\right), \delta$ $=70.03\left(\mathrm{C}-4^{\prime}\right), \delta=76.85\left(\mathrm{C}-5^{\prime}\right)$, and $\delta=61.05 \mathrm{ppm}(\mathrm{C}-$ 6') (Table 2; Additional file 1: Figure S8A\&B). The site of glycosylation at C-7 was confirmed by a correlation between the anomeric proton $\mathrm{H}-1$ ' at $\delta=5.03 \mathrm{ppm}$ and carbon C-7 at $\delta=160.68 \mathrm{ppm}$ of umbelliferone in Heteronuclear multiple-bond correlation spectroscopy (HMBC) analysis (Additional file 1: Figure S8C). These analyses identified that the glycosylated product was $7-O-\beta-\mathrm{D}$ glucopyranosyl umbelliferone, also known as skimmin [22].

Moreover, the ${ }^{1} \mathrm{H}$-NMR spectrum of the purified methylated product showed a set of signal at $\delta=3.86 \mathrm{ppm}$ 
Table 2 Umbelliferone in comparision with hydroxylated (esculetin), glucosylated (skimmin) and methylated umbelliferone (herniarin) on ${ }^{1} \mathrm{H}-\mathrm{NMR}$ and ${ }^{13} \mathrm{C}-\mathrm{NMR}$ analyses

\begin{tabular}{|c|c|c|c|c|c|c|c|c|}
\hline \multirow[t]{2}{*}{ Carbon No. } & \multicolumn{2}{|l|}{ Umbelliferone } & \multicolumn{2}{|l|}{ Esculetin } & \multicolumn{2}{|l|}{ Skimmin } & \multicolumn{2}{|l|}{ Herniarin } \\
\hline & ${ }^{1} \mathrm{H}$ NMR & ${ }^{13} \mathrm{C} \mathrm{NMR}$ & ${ }^{1} \mathrm{H}$ NMR & ${ }^{13} \mathrm{C}$ NMR & ${ }^{1} \mathrm{H}$ NMR & ${ }^{13} \mathrm{C}$ NMR & ${ }^{1} \mathrm{H}$ NMR & ${ }^{13} \mathrm{C} \mathrm{NMR}$ \\
\hline 2 & & 160.92 & & 158.21 & & 158.64 & & 160.77 \\
\hline 3 & $6.20(\mathrm{~d}, \mathrm{~J}=9.4 \mathrm{~Hz})$ & 111.87 & $6.70(\mathrm{~d}, J=2.3 \mathrm{~Hz})$ & 113.61 & $6.33(\mathrm{~d}, J=9.5 \mathrm{~Hz})$ & 113.75 & $6.30(\mathrm{~d}, J=9.4 \mathrm{~Hz})$ & 112.89 \\
\hline 4 & $7.93(\mathrm{~d}, \mathrm{~J}=9.4 \mathrm{~Hz})$ & 145.00 & $7.35(\mathrm{~d}, J=8.4 \mathrm{~Hz})$ & 127.73 & $8.01(\mathrm{~d}, J=9.5 \mathrm{~Hz})$ & 144.74 & $8.00(\mathrm{~d}, J=9.5 \mathrm{~Hz})$ & 144.84 \\
\hline $4 a$ & & 111.75 & & 112.72 & & 113.61 & & 101.19 \\
\hline 5 & $7.52(\mathrm{~s})$ & 130.18 & $7.06(s)$ & 116.69 & $7.65(\mathrm{~d}, \mathrm{~J}=8.6 \mathrm{~Hz})$ & 129.91 & $7.64(\mathrm{~d}, J=8.5 \mathrm{~Hz})$ & 129.97 \\
\hline 6 & $6.79(\mathrm{dd}, \mathrm{J}=8.4,2.3 \mathrm{~Hz})$ & 113.59 & & 139.02 & $7.05(\mathrm{~d}, J=2.3 \mathrm{~Hz})$ & 114.13 & $6.96(\mathrm{dd}, J=8.6,2.4 \mathrm{~Hz})$ & 112.96 \\
\hline 7 & & 161.76 & & 159.16 & & 160.68 & & 162.96 \\
\hline 8 & $6.72(s)$ & 102.63 & $\begin{array}{l}6.74(\mathrm{dd}, J=8.5 \\
2.3 \mathrm{~Hz})\end{array}$ & 102.36 & $7.02(\mathrm{dd}, J=8.6,2.3 \mathrm{~Hz})$ & 103.63 & $7.01(\mathrm{~d}, \mathrm{~J}=2.4 \mathrm{~Hz})$ & 75.85 \\
\hline $8 a$ & & 155.97 & & 151.00 & & 155.50 & & 155.91 \\
\hline $1^{\prime}$ & & & & & $5.03(\mathrm{~d}, J=7.5 \mathrm{~Hz})$ & 100.43 & & 56.42 \\
\hline $2^{\prime}$ & & & & & $3.44(\mathrm{dd}, J=10.9,6.1 \mathrm{~Hz})$ & 73.52 & & \\
\hline $3^{\prime}$ & & & & & $3.38-3.22(m)$ & 77.57 & & \\
\hline $4^{\prime}$ & & & & & $3.13(s)$ & 70.03 & & \\
\hline $5^{\prime}$ & & & & & $3.68(\mathrm{dd}, \mathrm{J}=2.9,1.1 \mathrm{~Hz})$ & 76.85 & & \\
\hline $6^{\prime}$ & & & & & $4.28(\mathrm{~d}, J=9.1 \mathrm{~Hz})$ & 61.05 & & \\
\hline \multicolumn{9}{|c|}{ Hydroxyl group } \\
\hline 7-OH & $10.59(\mathrm{~s})$ & & $9.84(\mathrm{~s})$ & & & & & \\
\hline $6-\mathrm{OH}$ & & & $10.09(\mathrm{~s})$ & & & & & \\
\hline \multicolumn{9}{|c|}{ Methyl group } \\
\hline $7-\mathrm{OCH}_{3}$ & & & & & & & $3.86(\mathrm{~s})$ & \\
\hline
\end{tabular}

$\mathrm{s}$ singlet, $\mathrm{d}$ doublet, dd doublet of doublet, $\mathrm{m}$ multiplet

(s, 3H) corresponding to a methyl group. Furthermore, the ${ }^{13} \mathrm{C}$-NMR showed ten carbons signals, including one new methyl group at $\delta=56.42 \mathrm{ppm}$ representing $\mathrm{O}-\mathrm{CH}_{3}$ group in comparison with the nine carbon signals of umbelliferone (Table 2; Additional file 1: Figure S9A\&B). The site of methylation at C-7 was confirmed by a correlation between methyl group and carbon C-7 at $\delta=162.95 \mathrm{ppm}$ of umbelliferone in $\mathrm{HMBC}$ analysis (Additional file 1: Figure S9C). These data confirmed that methylated product was 7-methoxycoumarin, also known as herniarin [21].

\section{Water solubility determination}

The data showed that the water solubility of herniarin was decreased by 1.89 -folds, whereas esculetin and skimmin were significantly improved by 1.28 and 3.98 -folds, respectively, compared to that of umbelliferone. These results indicated that hydroxylation and glycosylation of umbelliferone enhanced its water solubility by attachment of hydrophilic moieties, while methylation decreased its water solubility by attachment of hydrophobic methyl moiety.

\section{Antibacterial activities}

Results of disc diffusion assays showed that umbelliferone, esculetin, and skimmin did not exhibit any antibacterial activity against the tested five different human pathogens when $10 \mu \mathrm{L}$ of $100 \mathrm{mM}$ compound was applied. However, herniarin exhibited antibacterial activity against Gram-positive bacteria Staphylococcus aureus subsp. aureus KCTC 1916 (S. aureus) and Bacillus subtilis KACC 17047 (B. subtilis) with a zone of inhibition values of $9 \pm 0.12 \mathrm{~mm}$ and $8.5 \pm 0.18 \mathrm{~mm}$, respectively (Additional file 1: Table S1). These results revealed that methylation of umbelliferone at hydroxyl group of the C-7 position might be profitable for heightening its antibacterial activity against Gram-positive bacteria.

\section{Anticancer activities}

All prepared compounds were further evaluated for their in vitro cytotoxicity by 3-(4,5-dimethylthiazol-2-yl)-2,5diphenyltetrazolium bromide (MTT) colorimetric assay against four different cancer cell lines (Fig. 4). Results showed that herniarin exhibited good cytotoxic activities compared to the other three compounds. Cell viability of skin melanoma (B16F10), gastric carcinoma (AGS), 

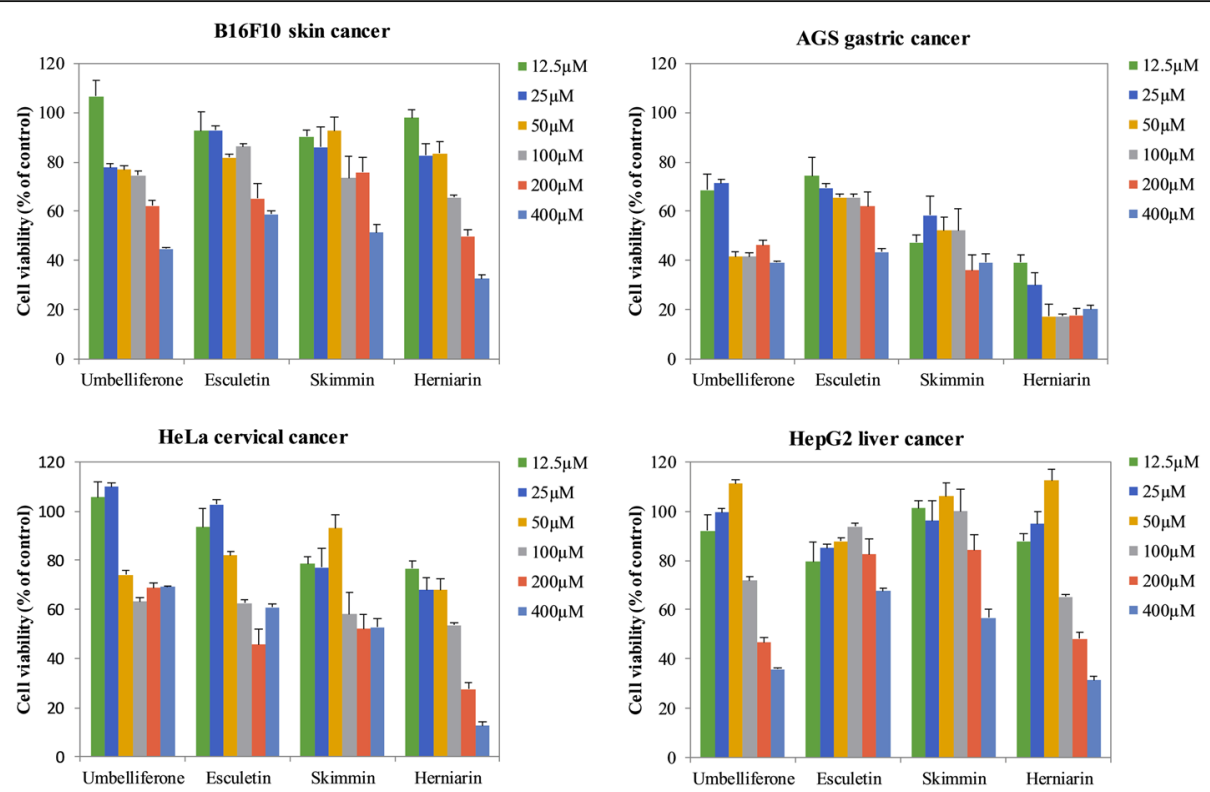

Fig. 4 The growth of four cancer cell lines were treated with umbelliferone and its derivatives

epitheliod cervix carcinoma (HeLa) and hepatic carcinoma (HepG2) reduced approximately 32.63\%, 20.25\%, 12.79\%, and $31.28 \%(p<0.05)$, respectively, compared to controls, when treated $400 \mu \mathrm{M}$ of herniarin. The $50 \%$ inhibitory concentration $\left(\mathrm{IC}_{50}\right)$ values of herniarin for B16F10, AGS, HeLa and HepG2 cells were 197.0, 28.29, 80.21, and $206.1 \mu \mathrm{M}$, respectively. Skimmin inhibited AGS cell lines with an $\mathrm{IC}_{50}$ value of $34.42 \mu \mathrm{M}$. However, esculetin did not show any activity against the tested cell lines, whereas umbelliferone exhibited effective anticancer activity against AGS and HepG2 cell lines with $\mathrm{IC}_{50}$ values of 129.9 and $222.3 \mu \mathrm{M}$, respectively (Additional file 1: Table S2). These results suggest that herniarin and skimmin can remarkable reduce the cell viability of AGS cell line in a dose-dependent manner. This is the first report of the activity of the two compounds against AGS cell line.

\section{Discussion}

Post-modifications of natural compounds is one of the approaches to enhance the biological and pharmaceutical properties of parent molecules [23]. In this research, we produced three umbelliferone derivatives using a monooxygenase, a glycosyltransferase, and a methyltransferase enzyme via microbial biotransformation in E. coli. First, umbelliferone was oxidized by CYP450 BM3 from $B$. megaterium and its variant M13 to produce metabolite esculetin. Second, a flexible glycosyltransferase YjiC from $B$. licheniformis capable of accepting various small molecules such as chalcone [24, 25], flavonoids [26], stilbene [27], and anthracycline antibiotic were used for efficient glycosylation of umbelliferone to produce skimmin [28]. Finally, we extended acceptor substrate of SaOMT2 from S. avermitilis [29] to produce herniarin. Our results suggest that modification of umbelliferone with different enzymes can be used to develop new compounds with novel biological activities.

Enzymatic methods were considerable contributed to the industrial production of pharmaceutical substances [30]. However, there are several shortcomings when utilizing an in vitro enzymatic synthesis approach. Most biocatalysts are limited by cofactor-dependent enzymes such as CYP BM3 which is NADPH-dependent cytochrome P450 [31] and YjiC, a UDP-dependent glycosyltransferase. In addition, NADPH, UDP-glucose, and S-adenosyl-Lmethionine (SAM) not only are high cost but also unstable to limit their apply in small scale stoichiometric reaction [32]. Although alternative cofactors-generating systems have been developed for large-scale reactions, the cost of reaction is still too expensive and reaction yield is deficient [33]. For example, only $8.09 \%$ and $35.48 \%$ of conversion rates from umbelliferone to esculetin were found in in vitro reactions with CYP450 BM3 and M13, respectively. Similarly, methylation reaction of SaOMT2 are limited convert substrate to herniarin (Table 1). Therefore, metabolic engineering and microbial biotransformation approaches are needed to further enhance the production by utilizing indigenous co-factors, ultimately lowering the cost of target molecule production.

Interestingly, the catalytic efficiency of M13 with umbelliferone was 4.39-folds higher than CYP450 BM3 in in vitro reaction. In addition, protein M13 showed higher catalytic efficiency for umbellifferone than wildtype CYP450 BM3 in whole cells for $48 \mathrm{~h}$ under the 
same condition (Table 2; Additional file 1: Figure S3). The long-distance between the heme iron at ferric resting state in the CYP450 BM3 and oxidizable carbon of umbelliferone is one of the reasons for the low bioconversion efficiency [34]. Furthermore, substitution of several key amino acids in the wild-type protein can affect on the activity and selectivity of the biocatalyst reaction. For example, arginine residues at position 47 is supposed to be noticeable for entering of the substrate to the channel and controlling substrate accessibility to the binding pocket [35]. The leucine residues at position 86 could be effective for conformational changes of amino acids near heme, resulting in alteration of the electron transfer pathway to increase activity [36]. The substitution of phenylalanine 87 can directly interact with bound substrates and affect the activity and stereo-selectivity or regioselectivity of enzymes [37]. It is possible that the substituted key amino acid in the wild type protein might have altered $\mathrm{CO}$ difference spectra of M13 in comparison with CYP450 BM3. These data indicate that protein engineering was powerful method for enhance the production of natural molecules. They also suggest that one way to improve the activity of SaOMT2 toward umbelliferone is by engineering via site-saturation mutagenesis based on the structural model of substrate binding site of the enzyme. Moreover, engineering of $\mathrm{YjiC}$ could advance metabolic engineering by tailoring compounds with high stereo-selectivity or regio-selectivity to achieve high yields of desired molecules [38].

We also studied the biological activities of umbelliferone and its three derivatives as such antibacterial and anticancer agents. Although the activities of four compounds were tested against five bacteria, only herniarin was effective against two Gram-positive bacteria $B$. subtilis and S. aureus. This indicated that the methyl substitution at the hydroxyl group of the C-7 position reduced the water solubility and showed significant antibacterial activity. The possible reason could explain that the enhanced lipophilicity of alkyl group leads to improving the ability of herniarin to overcome cell membrane [39], followed by coumarin-based inhibitors of bacteria replicative DNA helicase [40]. Similar to bacterial activity, among the four compounds, herniarin showed the most potential anticancer activity against four tested cancer cell lines. Although we accessed the activity of herniarin and skimmin against AGS cell line for the first time, these compounds could be used in further studies to reveal their exact mechanisms of action and their anticancer effects in vivo. The previous study has reported that umbelliferone have growth inhibitory effects on human cancer cell lines such as breast cancer (MCF-7) and lung cancer (H727) [41]. Esculetin did not show activity against the tested cell lines in this study. However, it has anti-proliferative effects on G361 human malignant melanoma [4] and U937 human leukemia cells [42] and. These results provide the ability that modification of umbelliferone might generate a promising anticancer agent against various cancer cell lines.

\section{Conclusion}

In conclusion, the results demonstrate that both native enzyme and engineered enzyme expressed in the whole cell allow producing the precious compounds. As a result we successfully produced three different molecules herniarin, esculetin and skimmin from umbelliferone using engineered microbial cells. The employed fermentation approach is cheaper than in vitro reaction and other chemical synthesis methods. The biosynthesized molecules were also accessed for their potential bioactivities against different pathogens and cancer cell lines. The present research suggests that the combinatorial biosynthesis of different biosynthetic enzymes could rapidly promote to a novel secondary metabolite.

\section{Methods \\ Chemicals and reagents}

Standard umbelliferone, $\delta$-aminolevulinic acid hydrochloride ( $\delta$-ALA), SAM, deuterium oxide $\left(\mathrm{D}_{2} \mathrm{O}\right)$, and DMSO- $\mathrm{d}_{6}$ were purchased from Sigma-Aldrich (USA). UDP- $\alpha$-Dglucose, $\alpha$-D-glucose 1 -phosphate, and isopropyl- $\beta$-Dthiogalactopyranoside (IPTG) were obtained from Genechem (Korea). NADP oxidized form was provided from Tokyo Chemical Industry Co., Ltd (Japan). HPLC-grade acetonitrile and water were purchased from Mallinckrodt Baker (Phillipsburg, NJ, USA). All other chemicals used were of analytical grade.

\section{Plasmids, microorganisms, and culture conditions}

Plasmid $\mathrm{pCW}\left(\mathrm{Ori}^{+}\right)$-mutant 13 (M13) carrying amino acid substitution relative to wild type CYP450 BM3: M13 (R47L/L86I/F87V/L188Q) [43] and pET28a-YjiC were constructed previously [24]. The sequence of previously characterized S. avermitilis derived OMT [29] was cloned using the first cloning site of pRSF-Duet vector to make recombinant plasmid pRSF-Duet-SaOMT2. These plasmids were transformed into E. coli BL21 (DE3) (Stratagene, USA) using standard procedures. $100 \mu \mathrm{g} / \mathrm{mL}$ of ampicillin and $50 \mu \mathrm{g} / \mathrm{mL}$ of kanamycin were used in LB medium for protein expression and biotransformation assay.

\section{Enzyme expression and purification}

E. coli $\mathrm{BL} 21$ (DE3) harboring recombinant $\mathrm{pCW}\left(\mathrm{Ori}^{+}\right)-\mathrm{P} 450$ BM3 with $\mathrm{pCW}\left(\mathrm{Ori}^{+}\right)$-mutant 13, pET28a-YjiC, and pRSF-Duet-SaOMT2 were cultured in LB broth containing appropriate antibiotics at $37^{\circ} \mathrm{C}$ and $180 \mathrm{rpm}$ for 6 h. $0.5 \mathrm{mM}$ IPTG and $1 \mathrm{mM} \delta$-ALA were used to expression of CYP450 BM3 and mutant 13 when cell 
optical density at $600 \mathrm{~nm}\left(\mathrm{OD}_{600 \mathrm{~nm}}\right)$ reached 0.6. These cells were further incubated for an additional $20 \mathrm{~h}$ at $28{ }^{\circ} \mathrm{C}$ before harvest. Furthermore, $0.5 \mathrm{mM}$ IPTG was used to induced for protein expression of pET28a-YjiC and pRSF-Duet-SaOMT2 at $20{ }^{\circ} \mathrm{C}$ for $20 \mathrm{~h}$. These cells were harvested by centrifugation at $842 \times g$ for $10 \mathrm{~min}$ and suspended twice in $100 \mathrm{mM}$ Tris- $\mathrm{HCl}(\mathrm{pH}$ 7.6) buffer containing $10 \%$ glycerol. Cells were suspended in $1 \mathrm{~mL}$ of the same buffer and lysed by sonication using a Sonosmasher (Ultrasonic, Inc.). Following centrifugation at $13,475 \times g$ for $30 \mathrm{~min}$ at $4{ }^{\circ} \mathrm{C}$, the protein fractions were applied across $12 \%$ sodium dodecyl sulfate polyacrylamide gel electrophoresis (SDS-PAGE). Amicon ${ }^{\circ}$ Ultra- $0.5 \mathrm{~mL}$ $100 \mathrm{~K}$ and $30 \mathrm{~K}$ devices (Merck, USA) were used to collect soluble cytosolic fraction of CYP450 BM3, mutant 13, and YjiC, SaOMT2, respectively. $100 \mathrm{mM}$ Tris- $\mathrm{HCl}$ (pH 7.6) buffer containing $10 \%$ glycerol was used to store solution fractions at $-20{ }^{\circ} \mathrm{C}$ until next use. CYP450 BM3 protein content $(\mathrm{nmol})=[$ (absorbance difference $\times$ 1000)/91 $\mathrm{mM}^{-1} \mathrm{~cm}^{-1}$ ] x dilution factor [44]. Protein concentration was determined via Bradford method [45].

\section{Enzyme essay}

The reaction mixture was performed in $200 \mu \mathrm{L}$ with $1 \mathrm{mM}$ substrate. Hydroxylation reaction contained $50 \mu \mathrm{g} /$ $\mathrm{mL}$ CYP450 BM3 or mutant 13, $100 \mathrm{mM}$ potassium phosphate buffer ( $\mathrm{pH} 7.6$ ), and $10 \mathrm{mM} \mathrm{MgCl} 2 \cdot 6 \mathrm{H}_{2} \mathrm{O}$. The sample was pre-incubated at $37{ }^{\circ} \mathrm{C}$ for $15 \mathrm{~min}$ and the reaction was initiated by the addition of NADPH regenerating system consisting of $10 \mathrm{mM}$ glucose-6-phosphate, $0.5 \mathrm{U}$ glucose-6-phosphate-dehydrogenase, and $0.5 \mathrm{mM}$ $\mathrm{NADP}^{+}$. Glucosylation reaction mixture was incubated with $2 \mathrm{mM}$ UDP- $\alpha$-D-glucose, $10 \mathrm{mM} \mathrm{MgCl}_{2}, 50 \mu \mathrm{g} / \mathrm{mL}$ purified YjiC in $100 \mathrm{mM}$ Tris-HCl buffer (pH 7.6). Methylation reaction contained $50 \mu \mathrm{g} / \mathrm{mL}$ of purified SaOMT2 and $10 \mathrm{mM} \mathrm{MgSO}_{4}$ with $2 \mathrm{mM} \mathrm{SAM}$ as methyl donor in $100 \mathrm{mM}$ Tris- $\mathrm{HCl}$ buffer (pH 7.6). Reactions were incubated at $37^{\circ} \mathrm{C}$ for $30 \mathrm{~min}$. These reactions were stopped by adding chilled methanol at twice volume followed by vigorous shaking for $15 \mathrm{~min}$. Mixtures were then centrifuged at $13,475 \times g$ for $30 \mathrm{~min}$. The supernatants were used to HPLC-PDA and HR-QTOF ESI/MS. The conversion percentage of each substrate was calculated through intergrated between substrate and product peak area. A calibration standard was created using different concentration of umbelliferone $(10,25,50,100$, and $200 \mu \mathrm{g} / \mathrm{mL})$.

\section{Whole cell biotransformation}

Seed cultures of E. coli BL21 (DE3) harboring recombinant plasmids were prepared in $6 \mathrm{~mL} \mathrm{LB}$ broth with appropriate antibiotics followed by incubation at $37{ }^{\circ} \mathrm{C}$ with shaking at $180 \mathrm{rpm}$ for approximately $6 \mathrm{~h}$. For whole cell reaction of CYP450 mutant $13,200 \mu \mathrm{L}$ of pre-inoculum was transferred into $250 \mathrm{ml}$ flask containing $50 \mathrm{~mL}$ of different media (LB, TB, 1x M9 minimal salt) with appropriate antibiotic and incubated at $37^{\circ} \mathrm{C}$. When $\mathrm{OD}_{600}$ reached 0.8 , the culture was induced with $1.0 \mathrm{mM}$ IPTG and $0.5 \mathrm{mM} \delta$-ALA and incubated at $28{ }^{\circ} \mathrm{C}$ for $12 \mathrm{~h}$. Biotransformation of E.coli harboring pET28a-YjiC and pRSF-Duet-SaOMT2 was induced by $0.5 \mathrm{mM}$ IPTG at $20{ }^{\circ} \mathrm{C}$ for $12 \mathrm{~h} .100 \mathrm{mM}$ umbelliferone was supplemented to the same samples. The culture was incubated for an additional $12 \mathrm{~h}$, collected, extracted and analyzed.

\section{Scale-up of whole cell biocatalyst system in a fermentor} Fermentation of three E.coli BL21 (DE3) recombinant strains (CYP450 mutant 13, YjiC, and SaOMT2) was carried out in 3-L media under optimal conditions as described previously $[34,46]$. The quantify of hydroxylated and methylated production were taken every $12 \mathrm{~h}$ until $48 \mathrm{~h}$. Likewise, glycosylated sample was taken every $3 \mathrm{~h}$ up to $15 \mathrm{~h}$. Then, culture broth was centrifuged. Finally, the supernatant was extracted with twice volume of EtOAc.

\section{Analytical methods}

The culture broth was extract with double volume of EtOAc (v/v = 2:1) using Soxhlet extractor. Soxhlet extractor was then kept still to separate two layers after the mixture was shaken for $12 \mathrm{~h}$ at room temperature. A rotary evaporator was used to dried EtOAc fraction. The products were analyzed by HPLC-PDA using a reversedphase column (Mightysil RP-18 GP 250-4.6 (5 $\mu \mathrm{m})$, Kanto Chemical, Japan) at $330 \mathrm{~nm}$. The binary mobile phases were include solvent $\mathrm{A}[0.05 \%$ trifluroacetic acid in HPLC-grade water] and solvent B (100\% acetonitrile). The total flow rate was kept at $1 \mathrm{~mL} / \mathrm{min}$ for $30 \mathrm{~min}$. The percentages of solvent $\mathrm{B}$ used were as follows: $0-15 \%$ (0-4 min), 45\% (4-10 min), 75\% (10-14 min), 90\% (14-20 min), 10\% (20-25 min), 10\% (25-30 min). The compounds were purified by preparative HPLC (Shimazu, Tokyo, Japan) with $\mathrm{C}_{18}$ column (YMC-Pack ODS-AQ $(250 \times 20 \mathrm{~mm}$ I.D., $10 \mu \mathrm{m})$ linked to a UV detector $(330 \mathrm{~nm})$. HR-QTOF ESI/MS analysis using an ACQUITY UPLC coupled with SYNAPT G2-S (Water Corp., USA). For NMR analysis of the purified product, compounds were dried, lyophilized, and dissolved in DMSO- $\mathrm{d}_{6}$ and subjected to $700 \mathrm{MHz}$ Bruker Biospin NMR for one-dimensional ${ }^{1} \mathrm{H}$-NMR, ${ }^{13} \mathrm{C}-\mathrm{NMR}$, and two-dimensional HMBC analyses.

\section{Solubility study}

$50 \mu \mathrm{M}$ of umbelliferone, esculetin, skimmin and herniarin were separately dissolved in $200 \mu \mathrm{L}$ phosphate-buffered saline (PBS) at $\mathrm{pH}$ 7.6. The mixtures were vortexed for $30 \mathrm{~min}$ and centrifuged at $13,475 \times \mathrm{g}$ for $15 \mathrm{~min}$. The supernatants were collected and filtered through $0.45-\mu \mathrm{m}$ 
syringe filters. Subsequently, aliquots $(20 \mu \mathrm{L})$ were analyzed by HPLC-PDA at $330 \mathrm{~nm}$. The concentrations of all compounds dissolved in PBS were determined by regression equations.

\section{Antibacterial activity}

Three Gram-positive bacteria (Staphylococcus aureus subsp. aureus KCTC 1916, Bacillus subtilis KACC 17047, and Micrococcus luteus KACC 13377) and two Gram-negative bacteria (Pseudomonas aeruginosa KACC 10232 and Enterobacter cloaceae subsp. disolvens KACC 13002) were used to test antibacterial activity of umbelliferone and its derivatives. The paper disc diffusion assay on Mueller-Hinton agar (MHA) plate were carried out. Inocula containing $10^{7}$ colony forming units $(\mathrm{CFU}) / \mathrm{mL}$ were spread onto MHA plates. $10 \mu \mathrm{L}$ of $100 \mathrm{mM}$ compounds were placed on the surface of inoculated agar plates through sterile filter paper discs. The samples were then incubated at $37{ }^{\circ} \mathrm{C}$ for $12 \mathrm{~h}$. The zone of inhibition diameter was measured in millimeter [47].

\section{Anticancer activities}

Four cencer cell lines (B16F10, AGS, HeLa, and HepG2) grown in Roswell Park Memorial Institute 1640 medium containing 10\% fetal bovine serum (FBS) (Invitrogen, USA) were applied to test anticancer activities of umbelliferone and its derivatives. All cells were maintained at $37{ }^{\circ} \mathrm{C}$ in a humidified $5 \%$ $\mathrm{CO}_{2}$ incubator. For cell growth assay, cells seeded at $2 \times 10^{3}$ cell/well in 96-well plates (SPL Life Sciences, Korea) were treated with each compound after serial dilution $(400 \mu \mathrm{M}, 200 \mu \mathrm{M}, 100 \mu \mathrm{M}, 50 \mu \mathrm{M}, 25 \mu \mathrm{M}$, $12.5 \mu \mathrm{M})$ for $72 \mathrm{~h}$. Cell viability was measured using MTT colorimetric assay [48].

\section{Statistical analysis}

Values are mean \pm standard deviation (SD). SD was calculated from the results of three independent experiments. Differences with $p$ value $<0.05$ were indicated a statistically significant.

\section{Additional files}

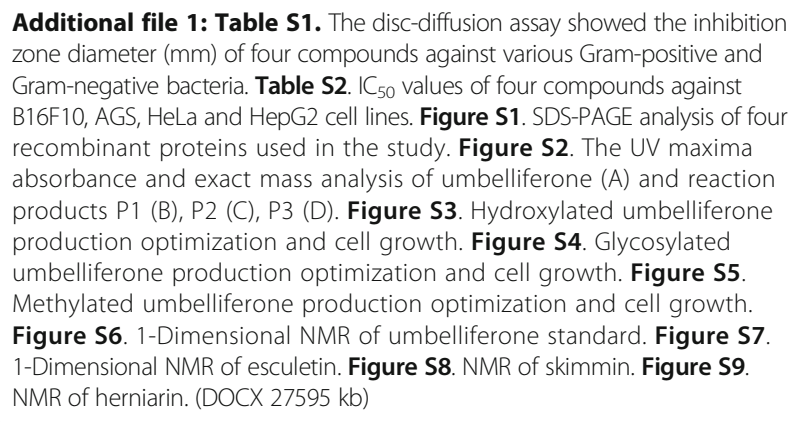

Additional file 1: Table S1. The disc-diffusion assay showed the inhibition zone diameter ( $\mathrm{mm}$ ) of four compounds against various Gram-positive and Gram-negative bacteria. Table $\mathbf{S 2}$. I $\mathbf{C}_{50}$ values of four compounds against B16F10, AGS, HeLa and HepG2 cell lines. Figure S1. SDS-PAGE analysis of four recombinant proteins used in the study. Figure S2. The UV maxima absorbance and exact mass analysis of umbelliferone (A) and reaction products P1 (B), P2 (C), P3 (D). Figure S3. Hydroxylated umbelliferone production optimization and cell growth. Figure S4. Glycosylated umbelliferone production optimization and cell growth. Figure S5 Methylated umbelliferone production optimization and cell growth. Figure S6. 1-Dimensional NMR of umbelliferone standard. Figure S7. 1-Dimensional NMR of esculetin. Figure S8. NMR of skimmin. Figure $\mathbf{S 9}$ NMR of herniarin. (DOCX $27595 \mathrm{~kb}$ )

\section{Abbreviations}

AGS: Gastric carcinoma; B16F10: Skin melanoma; DMSO: Dimethyl sulfoxide; HeLa: Epitheliod cervix carcinoma; HepG2: Hepatic carcinoma; HPLC-PDA: High performance liquid chromatography-photodiode array; HR-QTOF ESI/MS: High resolution-quadruple time of flight electrospray ionization/mass spectrometry; IPTG: Isopropyl- $\beta$-D-thiogalactopyranoside; NADP ${ }^{+}$; $\beta$-Nicotinamide adenine dinucleotide phosphate oxidized; NADPH: $\beta$-Nicotinamide adenine dinucleotide phosphate reduced; NMR: Nuclear magnetic resonance; $\delta$-ALA: $\delta$-aminolevulinic acid hydrochloride

\section{Acknowledgements}

Not applicable.

\section{Funding}

This work was funded by Cooperative Research Program for Agriculture Science and Technology Development (Project No. PJ01188001), Rural Development Administration, Republic of Korea.

\section{Availability of data and materials}

All data generated or analyzed during this study are included in this published article (and its supplementary information files).

\section{Authors' contributions}

LLC designed, performed the majority of the experiment work and wrote the manuscript. RPP and TSK helped in writing the manuscript. JKS and LCC were responsible for the original concept and supervised the work. HNL, $\mathrm{NHT}$ and HJJ did the majority of anticancer activities. All authors read and approved the final manuscript.

\section{Competing interests}

The authors declare that they have no competing interests.

\section{Consent for publication}

Not applicable.

\section{Ethics approval and consent to participate}

Not applicable.

\section{Publisher's Note}

Springer Nature remains neutral with regard to jurisdictional claims in published maps and institutional affiliations.

\section{Author details}

'Department of Life Science and Biochemical Engineering, Sun Moon University, 70 Sunmoon-ro 221, Tangjeong-myeon, Asan-si, Chungnam 31460, Republic of Korea. ${ }^{2}$ Department of BT-Convergent Pharmaceutical Engineering, Sun Moon University, 70 Sunmoon-ro 221, Tangjeong-myeon, Asan-si, Chungnam 31460, Republic of Korea. ${ }^{3}$ Center for Molecular Biology, Institute of Research and Development, Duy Tan University, K7/25 Quang Trung, Danang, Vietnam.

Received: 17 February 2017 Accepted: 23 March 2017

Published online: 05 April 2017

\section{References}

1. Rauf A, Khan R, Khan H, Pervez S, Pirzada AS. In vivo antinociceptive and anti-inflammatory activities of umbelliferone isolated from Potentilla evestita. Nat Prod Res. 2014;28:1371-4.

2. Kim SH, Kang KA, Zhang R, Piao MJ, Ko DO, Wang ZH, Chae SW, Kang SS, Lee $\mathrm{KH}$, Kang HK, Kang HW, Hyun JW. Protective effect of esculetin against oxidative stress-induced cell damage via scavenging reactive oxygen species. Acta Pharmacol Sin. 2008;29:1319-26.

3. Kimura Y, Sumiyoshi M. Antitumor and antimetastatic actions of dihydroxycoumarins (esculetin or fraxetin) through the inhibition of $M 2$ macrophage differentiation in tumor-associated macrophages and/or G1 arrest in tumor cells. Eur J Pharmacol. 2015;746:115-25.

4. Jeon YJ, Jang JY, Shim JH, Myung PK, Chae Jl. Esculetin, a coumarin derivative, exhibits anti-proliferative and pro-apoptotic activity in G361 human malignant melanoma. J Cancer Prev. 2015;20:106-12.

5. Subramaniam SR, Ellis EM. Neuroprotective effects of umbelliferone and esculetin in a mouse model of Parkinson's disease. J Neurosci Res. 2013;91:453-61. 
6. Shi J, Li CJ, Yang JZ, Yuan YH, Chen NH, Zhang DM. Coumarin glycosides and iridoid glucosides with neuroprotective effects from Hydrangea paniculata. Planta Med. 2012;78:1844-50.

7. Kumar V, Ahmed D, Verma A, Anwar F, Ali M, Mujeeb M. Umbelliferone B-Dgalactopyranoside from Aegle marmelos (L.) corr. an ethnomedicinal plant with antidiabetic, antihyperlipidemic and antioxidative activity. BMC Complement Altern Med. 2013;13:273.

8. Céspedes CL, Avila JG, Martínez A, Serrato B, Calderón-Mugica JC, Salgado-Garciglia R. Antifungal and antibacterial activities of Mexican tarragon (Tagetes lucida). J Agric Food Chem. 2006;54:3521-7.

9. Witaicenis A, Seito LN, da Silveira Chagas A, de Almeida Jr LD, Luchini AC, Rodrigues-Orsi P, Cestari SH, Di Stasi LC. Antioxidant and intestinal antiinflammatory effects of plant-derived coumarin derivatives. Phytomedicine. 2014;21:240-6

10. Venugopala KN, Rashmi V, Odhav B. Review on natural coumarin lead compounds for their pharmacological activity. Biomed Res Int. 2013;2013:963248.

11. Kai K, Mizutani M, Kawamura N, Yamamoto R, Tamai M, Yamaguchi H, Sakata K, Shimizu B. Scopoletin is biosynthesized via ortho-hydroxylation of feruloyl CoA by a 2-oxoglutarate-dependent dioxygenase in Arabidopsis thaliana. Plant J. 2008:55:989-99.

12. Balunas MJ, Kinghorn AD. Drug discovery from medicinal plants. Life Sci. 2005;8:431-41.

13. Al-Amiery AA, Musa AY, Kadhum AA, Mohamad AB. The use of umbelliferone in the synthesis of new heterocyclic compounds. Molecules. 2011;16:6833-43.

14. Alipour M, Khoobi M, Moradi A, Nadri H, Homayouni Moghadam F, Emami S, Hasanpour Z, Foroumadi A, Shafiee A. Synthesis and anti-cholinesterase activity of new 7-hydroxycoumarin derivatives. Eur J Med Chem. 2014;82:536-44.

15. Lin Y, Yan Y. Biosynthesis of caffeic acid in Escherichia coli using its endogenous hydroxylase complex. Microb Cell Fact. 2012;11:42.

16. Lin Y, Sun X, Yuan Q, Yan Y. Combinatorial biosynthesis of plant-specific coumarins in bacteria. Met Eng. 2013;18:69-77.

17. Yang SM, Shim GY, Kim BG, Ahn JH. Biological synthesis of coumarins in Escherichia coli. Microb Cell Fact. 2015;14:65.

18. Berner M, Krug D, Bihlmaier C, Vente A, Müller R, Bechthold A. Genes and enzymes involved in caffeic acid biosynthesis in the actinomycete Saccharothrix espanaensis. J Bacteriol. 2006;188:2666-73.

19. Yan Y, Chemler J, Huang L, Martens S, Koffas MA. Metabolic engineering of anthocyanin biosynthesis in Escherichia coli. Appl Environ Microbiol. 2005; $71: 3617-23$.

20. Thompson EB, Aynilian GH, Dobberstein RH, Cordell GA, Fong HH, Farnsworth NR. Biological and phytochemical investigation of plants XV. Ptenxia terebinthina var. terebinthina (Umbelliferae). J Nat Prod. 1979:42:120-5.

21. Silván AM, Abad MJ, Bermejo P, Sollhuber M, Villar A. Antiinflammatory activity of coumarins from Santolina oblongifolia. J Nat Prod. 1996;59:1183-5.

22. Okuyama T, Takata M, Shibata S. Structures of linear furano- and simplecoumarin glycosides of Bai-Hua Qian-Hu. Planta Med. 1989;55:64-7.

23. Chen J, Li W, Yao H, Xu J. Insights into drug discovery from natural products through structural modification. Fitoterapia. 2015;103:231-41.

24. Pandey RP, Li TF, Kim EH, Yamaguchi T, Park YI, Kim JS, Sohng JK. Enzymatic synthesis of novel phloretin glucosides. Appl Environ Microbiol. 2013;79:3516-21.

25. Li HM, Lee JK, Nie L, Huo Q, Ma T, Sohng JK, Hong YS, Wu CZ. Enzymatic synthesis of novel isobavachalcone glucosides via a UDP-glycosyltransferase. Arch Pharm Res. 2015;38:2208-15.

26. Gurung RB, Kim EH, Oh TJ, Sohng JK. Enzymatic synthesis of apigenin glucosides by glucosyltransferase (YjiC) from Bacillus licheniformis DSM 13. Mol Cells. 2013;36:355-61.

27. Shin JY, Pandey RP, Jung HY, Chu LL, Park YI, Sohng JK. In vitro single-vesse enzymatic synthesis of novel Resvera-A glucosides. Carbohydr Res. 2016:424:8-14

28. Chu LL, Pandey RP, Shin JY, Jung HY, Sohng JK. Synthetic analog of anticancer drug daunorubicin from daunorubicinone using one-pot enzymatic UDP-recycling glycosylation. J Mol Catal B-Enzym. 2016;124:1-10.

29. Kim BG, Jung BR, Lee Y, Hur HG, Lim Y, Ahn JH. Regiospecific flavonoid 7-Omethylation with Streptomyces avermitilis O-methyltransferase expressed in Escherichia coli. J Agric Food Chem. 2006;54:823-8.

30. Meyer HP, Eichhorn E, Hanlon S, Lütz S, Schürmann M, Wohlgemuth R, Coppolecchia R. The use of enzymes in organic synthesis and the life sciences: perspectives from the Swiss Industrial Biocatalysis Consortium (SIBC). Catal Sci Technol. 2013;3:29-40.
31. Mazur CS, Kenneke JF, Goldsmith MR, Brown C. Contrasting influence of NADPH and a NADPH-regenerating system on the metabolism of carbonyl-containing compounds in hepatic microsomes. Drug Metab Dispos. 2009;37:1801-5.

32. Uppada V, Bhaduri S, Noronha SB. Cofactor regeneration-an important aspect of biocatalysis. Curr Sci. 2014;106:946-57.

33. Zhao $\mathrm{H}$, van der Donk WA. Regeneration of cofactors for use in biocatalysis. Curr Opin Biotechnol. 2003;14:583-9.

34. Chu LL, Pandey RP, Jung N, Jung HJ, Kim EH, Sohng JK. Hydroxylation of diverse flavonoids by CYP450 BM3 variants: biosynthesis of eriodictyol from naringenin in whole cells and its biological activities. Microb Cell Fact. 2016;15:135.

35. Whitehouse CJ, Bell SG, Wong LL. P450(BM3) (CYP102A1): connecting the dots. Chem Soc Rev. 2012;41:1218-60.

36. Stjernschantz E, van Vugt-Lussenburg BM, Bonifacio A, de Beer SB, van der Zwan G, Gooijer C, Commandeur JN, Vermeulen NP, Oostenbrink C. Structural rationalization of novel drug metabolizing mutants of cytochrome P450 BM3. Proteins. 2008;71:336-52.

37. Graham-Lorence S, Truan G, Peterson JA, Falck JR, Wei S, Helvig C, Capdevila $\mathrm{JH}$. An active site substitution, F87V, converts cytochrome P450 BM-3 into a region- and stereoselective $(14 S, 15 R)$-arachidonic acid epoxygenase. J Biol Chem. 1997;272:1127-35.

38. Foo JL, Ching CB, Chang MW, Leong SS. The imminent role of protein engineering in synthetic biology. Biotechnol Adv. 2012;30:541-9.

39. John GT. Lipophilicity in drug action and toxicology. In: Pliška V, Testa B, van de Waterbeemd H, editors. Journal medicinal chemistry, vol. 39. Weinheim: VCH; 1996. p. 5287-8.

40. Li B, Pai R, Di M, Aiello D, Barnes MH, Butler MM, Tashjian TF, Peet NP, Bowlin TL, Moir DT. Coumarin-based inhibitors of Bacillus anthracis and Staphylococcus aureus replicative DNA helicase: chemical optimization, biological evaluation, and antibacterial activities. J Med Chem. 2012;55:10896-908.

41. Musa MA, Cooperwood JS, Khan MO. A review of coumarin derivatives in pharmacotherapy of breast cancer. Curr Med Chem. 2008;15:2664-79.

42. Park C, Jin CY, Kim GY, Choi IW, Kwon TK, Choi BT, Lee SJ, Lee WH, Choi YH. Induction of apoptosis by esculetin in human leukemia U937 cells through activation of JNK and ERK. Toxicol Appl Pharmacol. 2008;227:219-28.

43. Kim DH, Kim KH, Kim DH, Liu KH, Jung HC, Pan JG, Yun CH. Generation of human metabolites of 7-ethoxycoumarin by bacterial cytochrome P450 BM3. Drug Metab Dispos. 2008;36:2166-70.

44. Omura T, Sato R. The carbon monoxide-binding pigment of liver microsomes I. Evidence for its hemoprotein nature. J Biol Chem. 1964;239:2370-8.

45. Bradford MM. A rapid and sensitive method for the quantitation of microgram quantities of protein utilizing the principle of protein-dye binding. Anal Biochem. 1976;72:248-54.

46. Pandey RP, Malla S, Simkhada D, Kim BG, Sohng JK. Production of 3-O-xylosyl quercetin in Escherichia coli. Appl Microbiol Biotechnol. 2013;97:1889-901.

47. Kuppusamy P, Yusof MM, Parine NR, Govindan N. Evaluation of in vitro antioxidant and antibacterial properties of Commelina nudiffra L. extracts prepared by diffrent polar solvents. Saudi J Biol Sci. 2015;22:293-301.

48. Jung $\mathrm{HJ}$, Lee HB, Lim CH, Kim CJ, Kwon HJ. Cochlioquinone A1, a new antiangiogenic agent from Bipolaris zeicola. Bioorg Med Chem. 2003;11:4743-7.

\section{Submit your next manuscript to BioMed Central and we will help you at every step:}

- We accept pre-submission inquiries

- Our selector tool helps you to find the most relevant journal

- We provide round the clock customer support

- Convenient online submission

- Thorough peer review

- Inclusion in PubMed and all major indexing services

- Maximum visibility for your research

Submit your manuscript at www.biomedcentral.com/submit 